\title{
A new species for Mongolia and new records of vascular plants from Dzungarian Gobi
}

\author{
Sh. Baasanmunkh, B. Oyuntsetseg², G. A. Lazkov, G. Y. Chung ${ }^{4}$, H. J. Choi ${ }^{1}$ \\ ${ }^{1}$ Department of Biology \& Chemistry, Changwon National University, Changwon, 51140, South Korea. \\ E-mail:hjchoi1975@changwon.ac.kr
}

${ }^{2}$ Department of Biology, School of Arts and Science, National University of Mongolia, Ulaanbaatar, 14201, Mongolia. E-mail: oyunaa@num.edu.mn

${ }^{3}$ Laboratory of Flora, Institute of Biology, National Academy of Science, Bishkek, 720071, Kyrgyzstan. E-mail: glazkov1963@mail.ru

${ }^{4}$ School of Bioresource Science, Andong National University, Andong, 760-749, South Korea. E-mail: gychung@andong.ac.kr

*Corresponding author: baasanmunkh.sh@gmail.com

Keywords: Cortusa matthioli subsp. altaica, distribution, Mongolian flora, phytogeographical regions, Polygonatum odoratum, Pyrola rotundifolia, Ranunculus turczaninovii, Rubus saxatilis, Silene alexandrae.

Summary. A record of Silene alexandrae B. Keller converts it to a new species for Mongolia. S. alexandrae was found on the Khavtag Mountain ranges in Dzungarian Gobi region. Data about previous records of this species in Mongolia are discussed and rejected. Characters distinguishing Silene alexandrae from close species S. altaica Pers. are given. We noted also new distribution points of five taxa: Cortusa matthioli L. subsp. altaica (Losinsk.) Korobkov, Ranunculus turczaninovii (Luferov) Vorosch., Rubus saxatilis L., Polygonatum odoratum (Mill.) Druce and Pyrola rotundifolia L. - in Dzungarian Gobi region of Mongolia.

\section{Новый вид для Монголии и новые находки сосудистых растений из Джунгарской Гоби}

\author{
Ш. Баасанмунх ${ }^{1 *}$, Б. Оюунцэцэг ${ }^{2}$, Г. А. Лазьков ${ }^{3}$, Г. Я. Чунг ${ }^{4}$, Хёк Чже Чой ${ }^{1}$ \\ ${ }^{1}$ Чханвонский Национальный университет, факультет биологии и химии, г. Чханвон, 51140, Южная Корея \\ ${ }^{2}$ Монгольский Национальный университет, факультет биологии, Школа искусства и науки, \\ 2. Улан-Батор, 14201, Монголия \\ ${ }^{3}$ Институт биологии Национальной Академии наук, лаборатория флоры, г. Биикек, 720071, Кыргызстан \\ ${ }^{4}$ Андонский Национальный университет, Школа биоресурсов, г. Андон, 760-749, Южная Корея \\ *Aвтор для переписки: baasanmunkh.sh@gmail.com
}

Ключевые слова: ботанико-географический район, монгольская флора, распространение, Cortusa matthioli subsp. altaica, Polygonatum odoratum, Pyrola rotundifolia, Ranunculus turczaninovii, Rubus saxatilis, Silene alexandrae.

Аннотация. Сообщается о находке Silene alexandrae B. Keller - нового вида для флоры Монголии, который был найден в горах Хавтаг, регионе Джунгарской Гоби. Обсуждены и отвергнуты предыдущие данные 
о распространении этого вида в Монголии. Приводятся признаки, отличающие данный вид от S. altaica Pers. В регионе Джунгарской Гоби Монголии впервые отмечены следующие таксоны: Cortusa matthioli L. subsp. altaica (Losinsk.) Korobkov, Polygonatum odoratum (Mill.) Druce и Pyrola rotundifolia L., Ranunculus turczaninovii (Luferov) Vorosch., Rubus saxatilis L.

\section{Introduction}

A total of 3160 species of vascular plants, which belong to 684 genera and 108 families, have been recorded in the flora of Mongolia to date (Gubanov, 1996; Urgamal et al., 2014, 2016). According to the latest classification by Grubov and Yunatov (1952), Mongolia is divided into sixteen phytogeographical regions based on floral composition, vegetation and geographical characteristics. From these, two regions we surveyed, Mongolian Altai (MA) and Dzungarian Gobi (DzG), locate in the western part of Mongolia.

The Dzungarian Gobi region is the extreme west of Gobi, which locates in Khovd province of Mongolia and near borders with China. Despite it is one of the desert regions of Mongolia (Grubov, 1982), several high mountains, such as Baitag Bogd (3400 m), Khavtag (2800 m), Takhiin Shar nuruu $(2727 \mathrm{~m})$, Khalzan $(2105 \mathrm{~m})$ and Mergen $(1883 \mathrm{~m})$ occur here. Due to this, different plant communities developed in this region and vicinity of the mountains have relatively high diversity of plant species compared to the lowland desert area in DzG (Darikhand, 2017, mscr.).

Several important floristic surveys conducted in the $\mathrm{DzG}$ region and number of new records of plants, new distribution points and plant communities were noted by von Wehrden et al. (2006), Oyuntsetseg et al. (2013), Kechaykin et al. (2014), Bekket et al. (2015) and Darikhand (2017, mscr.). In total, there are 879 species noted in the Dzungarian Gobi region, which shares $27.81 \%$ of the Mongolian flora (Grubov, 1982; Urgamal et al., 2016; Oyuntsetseg et al., 2017). Researchs on flora and vegetation of Mongolia are still ongoing with higher rate than even before. Yet, floristic richness in western part of Mongolia is high and DzG regions is home to many rare and unknown species. In the present study, we record one new species and five new distribution points of vascular plants, which are new points for $\mathrm{DzG}$ region.

\section{Material and Method}

Our botanical expeditions to Khavtag and Baitag Bogd mountains have been carried out in August, 2013 and 2017 in DzG region. The herbarium materials were collected and photographs of fertile specimens in natural habitat were taken during the field trips. The voucher specimens are deposited in the herbarium of the National University of Mongolia (UBU). For species determination and comparison, we checked herbarium (UBU), electronic data of species information and herbarium materials from the "Moscow University Herbarium (MW)" (https:// plant.depo.msu.ru; Seregin, 2016).

During our field trips, we found Silene alexandrae B. Keller in DzG region. In addition, new distribution points of five species in $\mathrm{DzG}$ region have been recorded. In the enumeration, the new for Mongolia species is cited with the nomenclature, commonly known synonyms, morphological description, ecology, phenology and geographical distribution. The new records in Dzungarian Gobi region are listed alphabetically with references to previously known distribution of taxa.

\section{Result and Discussion}

\section{New species for Mongolia}

Silene alexandrae B. Keller, 1912, Trav. Soc. Nat. (Kazan) 44 (5): 71, fig. 1A, B.

$=S$. altaica Pers. var. b. grandflora Fisch. et C. A. Mey. 1835, Ind. Sem. Hort. Petrop. 2: 87.

$=$ S. altaica Pers. var. hystrix Trautv. 1860, Bull. Soc. Nat. Mosc. 33(1): 151.

Type: East Kazakhstan "Kaldzhir valley on left side of Kaldzhir river, Chiganchiy, shale mountains, 22-23 VI 1908. B. A. Keller" (lectotypus LE!, designated by Lazkov, 2002: 129; isolectotype LE!).

Species examined (new record): "Mongolia, Dzungarian Gobi region, Khovd province, Altai sum, Khavtag Mountain range, $2686 \mathrm{~m}, 45^{\circ} 09^{\prime} 08.3^{\prime}$ N , 9209'01.4”'E. 20 VII 2014, Sh. Baasanmunkh, B. Oyuntstetseg" (UBU).

\section{Taxonomic notes:}

The genus Silene L. includes 24 reported species in Mongolia (Urgamal et al., 2014). Species S. altaica together with $S$. alexandrae closely related and sometimes included in last one species belongs to section Suffruticosae (Rohrb.) Schischk. However, $S$. alexandrae is different by several morphological characters such as shoots of the leaves located at the base of the stems, where they form a turf or a pillow, 
flowering stems poorly covered with leaves and look like a flower-bearing scapes, calyx $1.8-2.5 \mathrm{~cm}$ long, glabrous androgynophore $8-10 \mathrm{~mm}$, versus S. altaica has no shoots of leaves, forms turf or a pillow at the base of the stems, all leaves are evenly distributed along the stem, calyx 1.4-1.6 cm long, subglabrous, short hairy androgynophore 4-6 mm.

$S$. alexandrae has been described by B. Keller from Zaisan lake (between Kaldzhir and Chiganchi river) of Kazakhstan. In "Flora of China" edition
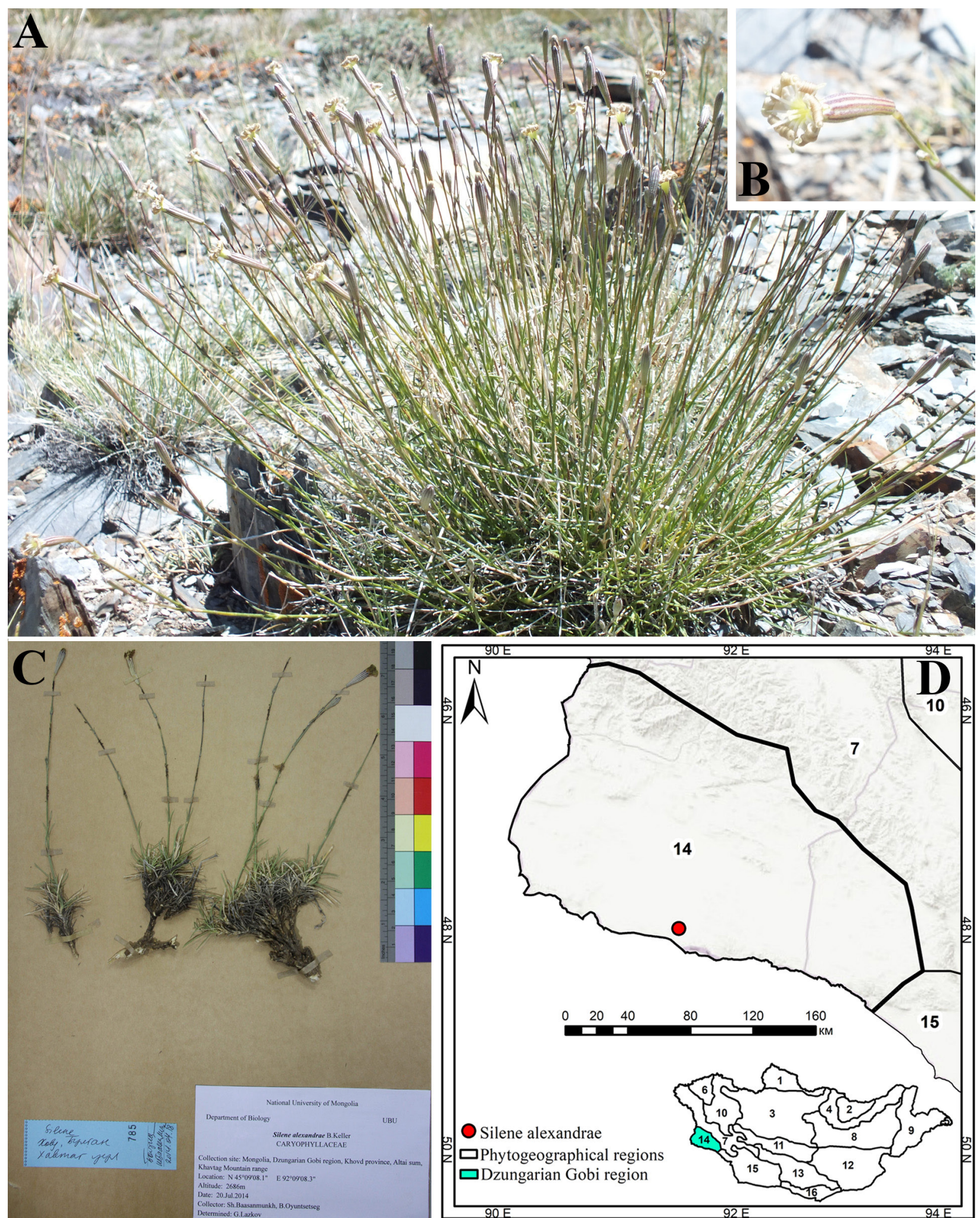

Fig. 1. Silene alexandrae B. Keller from Mongolia: A - general habitat in rocky and stony mountains; B - calyx; C herbarium; D - distribution map. 
this species is indicated from Dzungaria, China (N Xinjiang) (Zhou et al., 2001). This species has been reported from Mongolia by Sanchir et al. (1985) and Kozevnikov (1994). But these records were based on misidentification of $S$. gubanovii Lazkov (Gubanov, 1996) and corrected. Now, we found S. alexandrae newly from Dzungarian Gobi region of Mongolia and thereby it becomes new native species to Mongolia.

Probably, S. alexandrae has been reported before from Mongolia under the name $S$. altaica (Grubov, 1982). But no true specimens of $S$. altaica have been seen by us from Mongolia in different herbariums (LE, MW, UBU). According herbarium studies, specimens from Mongolia which reported as Silene altaica by Kozevnikov (1994) are in fact S. gubanovii as well.

Habitat: Species distributes in subalpine zone and grows in rocky and stony slopes.

Phenology: Flowering time is between June to July, and fruiting in August.

General distribution: China and Kazakhstan.

\section{New records in Dzungarian Gobi region}

Cortusa matthioli L. subsp. altaica (Losinsk.) Korobkov: "Dzungarian Gobi, Khovd province, Bulgan sum, Baitag Bogd mountain, Buduun

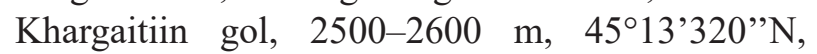
$90^{\circ} 55^{\prime} 221$ 'E. 12 VI 2013. Oyuntstetseg et al." (UBU). - It was previously known from several regions, e. i. Khangai, Khuvsgul, Mongolian Altai, Khentei and Gobi Altai of Mongolia (Gubanov, 1996; Urgamal et al., 2014). Moreover, we found it in $\mathrm{DzG}$ region in 2013.

Polygonatum odoratum (Mill.) Druce: "Dzungarian Gobi, Khovd province, Bulgan sum, Baitag Bogd mountain, Buduun Khargaitiin gol, 2220 m, 45 14 '44”'N, 9056'10”'E. 28 VIII 2013, Oyuntstetseg et al." (UBU). - It was previously known from several regions, e. i. Khangai, Khentei, Khuvsgul, Mongolian Dauria, foothills of Great
Khingan, Middle Khalkha and East Mongolia in Mongolia (Grubov, 1982; Gubanov, 1996; Urgamal et al., 2014). Moreover, we found it from DzG region in 2013.

Pyrola rotundifolia L.: "Dzungarian Gobi: Khovd province, Bulgan sum, Baitag Bogd mountain, Buduun Khargaitiin gol, $2220 \mathrm{~m}, 45^{\circ} 14^{\prime} 44^{\prime \prime} \mathrm{N}$, 9056'10"E. 11 VIII 2017. Sh. Baasanmunkh et al." (UBU). - It was previously recorded in several regions, e. i. Khangai, Khuvsgul, Khentei, Mongolain Dauria and Mongolian Altai of Mongolia (Gubanov, 1996; Urgamal et al. 2014). In addition, we recorded it from DzG region in 2017.

Ranunculus turczaninovii (Luferov) Vorosch.: "Dzungarian Gobi, Khovd province, Bulgan sum, Baitag Bogd mountain, Buduun Khargaitiin gol, 2318 m, 4514'066”N, 9055'499”'E. 13 VI 2013. Oyuntstetseg et al." (UBU). - It has been newly recorded only from Khentei region to Mongolian flora by Nobis et al. (2017). In addition, we noted it from $\mathrm{DzG}$ region which was known as second location in Mongolian flora.

Rubus saxatilis L.: "Dzungarian Gobi, Khovd province, Altai sum, Khavtag mountain range, 2686 m, 4602'10"'N, 92¹8'40” E. 03 VIII 2013. Oyuntstetseg et al." (UBU). - It was formerly noted in several regions, e. i. Khangai, Khentei, Khuvsgul, Mongolian Dauria, foothills of Great Khingan and East Mongolia of Mongolia (Grubov, 1982; Gubanov, 1996; Urgamal et al., 2014). Moreover, we found it from DzG region in 2013.

\section{Acknowledgements}

This research was supported by the research project ("A survey on the vascular flora of Mongolia"; Grant Number KNA 1-2-20, 14-4) of the Korean National Arboretum, South Korea, and Watercope Project funded by the International Fund for Agricultural Development (IFAD), Germany. We thank our colleague Kh. Oyundelger who discussed our first manuscript.

\section{REFERENCES}

Bekket U., Kechaykin A. A., Yevdokimov I. Yu., Kosachev P. A., Shmakov A. I. 2015. New findings about flora of West Mongolia. Acta Biologica Sibirica 1-2: 132-139 [In Russian]. (Беккет У., Кечайкин А. А., Евдокимов И. Ю., Косачев Р. А., Шмаков А. И. Новые находки во флоре Западной Монголии // Acta Biologica Sibirica, 2015. T. 1-2. C. 132-139). DOI: 10.14258/abs.v1i1-2

Darikhand D. 2017. The study of flora in northern part of Baitag Bogd Mountain. PhD thesis [In Mongolian], mscr.

Gubanov I. A. 1996. Konspekt flory Vneshney Mongolii (sosudistyye rasteniya) [Conspectus of the flora of Outer Mongolia (vascular plants)]. Valang Press, Moscow, 136 pp. [In Russian]. (Губанов И. А. Конспект флоры Внешней Монголии (сосудистые растения). М.: Валанг, 1996. 136 с.). 
Grubov V. I. 1982. Opredelitel sosudistykh rasteniy Mongolii (s atlasom) [Key to vascular plants of Mongolia (with an atlas)]. Nauka, Leningrad, 443 pp. [In Russian]. (Грубов В. И. Определитель сосудистых растений Монголии (с атласом). Л.: Наука, 1982. 443 с.).

Grubov V. I., Yunatov A. A. 1952. The main features of the flora of the Mongolian Popular Republic in connection with its zoning. Bot. Zhurn. (Moscow \& Leningrad) 37(1): 45-64 [In Russian]. (Грубов В. И., Юнатов А. А. Оcновные особенности флоры Монгольской Народной Республики в связи с ее районированием // Бот. журн., 1952. T. 37, № 1. C. 45-64).

Kechaykin A. A., Shmakov A. I., Hurka H., Neuffer B., Oyuntsetseg B., Darikhand D., Friesen N. 2014. New findings in the flora of Mongolia. Part 1. Turczaninowia 17, 1: 57-65 [In Russian]. (Кечайкин А. А., Шмаков А. И., Хурка Г., Нойффер Б., Оюнцэцэг Б., Дариханд Д., Фризен Н. Новые находки во флоре Монголии. Часть 1. // Turczaninowia, 2014. Т. 17, вып. 1. C. 57-65). DOI: 10.14258/turczaninowia.17.1.6

Kozhevnikov Yu. P. 1994. Fam. Caryophyllaceae Juss. In: Plantae Asiae Centralis (secus materies Instituti botanici nomine V. L. Komarovii). Fas. 11. World and Family, St. Petersburg, 13-117 pp. [In Russian]. (Кожсевников Ю. П. Caryophyllaceae Juss. // Растения Центральной Азии. Вып. 11. СПб.: «Мир и семья», 1994. С. 13-117).

Lazkov G. A. 2002. Type specimens of Central Asien species of genera Lychnis, Melendrium, Physolychnis, Silene (Caryophyllaceae) in the herbarium of Komarov Botanical Institute (LE). Bot. Zhurn. (Moscow \& Leningrad) 87(5): 128-135 [In Russian]. (Лазьков Г. A. Tиповые образиы Среднеазиатских видов Lychnis, Melendrium, Physolychnis, Silene (Caryophyllaceae), хранящиеся в Гербарии Ботанического Института им. В. Л. Комарова РAH (LE) // Бот. журн., 2002. T. 87, № 5. C. 128-135).

Nobis M., Erst A., Nowak A., Shaulo D., Olonova M., Kotukhov Y., Doğru-Koca A., Dönmez A. A., Király G, Ebel A. L., Kushunina M., Piwowarczyk R., Sukhorukov A. P, Nobis A., Verloove F., Zalewska-Gatosz J., Zare G., Burri J. F, Caković D., Jędrzejczak E., Nejc Jogan N., Ewelina Klichowska E., Pliszko A., Popovich A. V., Stešević D., Šilc U., Tupitsyna N., Vasjukov V. M., Wang W., Werner P., Wolanin M. N., Wolanin M. M., Xiang K-L. 2017. Contribution to the flora of Asian and European countries: new national and regional vascular plant records, 6. Botany Letters 164: 1, 23-45. DOI: 10.1080/23818107.2016.1273134

Oyuntsetseg B., Baasanmunkh Sh., Oyundelger Kh., Munkhzul O., Kim J. Y., Cho H. J., Batkhuu N., Chung G. Y., Choi H. J. 2017. Contribution to the knowledge on the flora of Munkhkhairkhan mountain area, Mongolia. Journal of Asia Pasific Biodiversity 10: 573-582. DOI: 10.1016/j.japb.2017.05.005.

Oyuntsetseg B., Friesen N. W., Darikhand D. 2013. Allium carolinianum DC. A new species to the outer Mongolia. Turczaninowia 16, 2: 88-90.

Sanchir Ch., Rachkovskaya K. I., Buyan-Orshikh Kh. 1985. New findings of the plants. Izv. Ac. Sc. MPR, ser. Biol. 3(97): 49-57 [In Mongolian]. (Санчир Ч., Рачковская К. И., Буян-Ориих Х. Urgamlyn shine sonirkholtoy oldvor // Изв. Акад. наук МНР, 1985. Т. 3(97). С. 49-57).

Seregin A. 2016. Making the Russian flora visible: fast digitisation of the Moscow university herbarium (MW) in 2015. Taxon 65 (1): 203-209.

Urgamal M., Oyuntsetseg B., Gundegmaa V., Munkh-Erdene T., Solongo Kh. 2016. Additions to the Vascular Flora of Mongolia - III. Proceeding of the Mongolian Academy of Sciences 56: 32-38.

Urgamal M., Oyuntsetseg B., Nyambayar D., Dulamsuren Ch. 2014. Conspectus of the Vascular Plants of Mongolia. Admon Press, Ulaanbaatar, 344 pp.

Von Wehrden H., Wesche K., Tungalag R. 2006. Plant communities of the Great Gobi B Strictly Protected Area, Mongolia. Mongolian Journal of Biological Sciences 4: 63-66.

Zhou L. H., Wu Z. Y., Liden M., Oxelmen B. 2001. Silene L. In: Flora of China. Vol. 6. Eds. Z.-Y. Wu, P. H. Raven. Science Press, Beijing, Botanical Garden Press, Missouri, 66-101 pp. 